\title{
Evaluation of Carrying Capacity Lands for Food Agriculture Based on Land Degradation in Pagar Alam City - Indonesia
}

\author{
Ratna Wilis, Eri Barlian, Dedi Hermon, Indang Dewata, Iswandi Umar
}

\begin{abstract}
The purpose of this research is a) analyzing the Land of paddy land change in South Sumatera province, and b) analyzing the capacity to support agricultural land-based food crops degraded land in Pagar Alam City. This research uses a quantitative descriptive approach, with variables are about changing land-use using the Geographic information systems (GIS). The results showed that the most extensive land-use in 2007 was mixed bush dryland agriculture (40339.45 Ha), while in 2019 was paddy land (24195.47 $\mathrm{Ha})$. The result of carrying capacity land value is 4.34, which means that the region can carry out food self-sufficiency and can provide a decent living for the population. Most of Pagar Alam City region has land suitability in the range of class II-IV. In general, for the future, the area in Pagar Alam City still has the potential to be developed for agricultural activities.
\end{abstract}

Keywords: land-use, carrying capacity, degradation.

\section{INTRODUCTION}

$T_{h}$ The rapidly increasing population accompanied by and increased production [1]. Land area in the agriculture sector is relatively larger than the land in other sectors so that agricultural land is considered to be very potential to be carried overland function to the non-agricultural sector [2]. The needs of land for infrastructure development (road, toll, airport, port, industrial, office) and residential (real estate) and resident settlements, itself has been expanding to land that has been the centre of paddy production. Usually, the developers will enjoy the paddy lands because the paddy lands are usually flat, close to the road and near the water source [3]. The conversion of paddy lands has become a serious threat to food security due to its impact on food

Revised Manuscript Received on May 15, 2020.

* Correspondence Author

Ratna Wilis*, his/her Department of geography and doctoral program of environmental science, Universitas Negeri Padang, Padang, Indonesia. Email: ratna_geounp@yahoo.com

Eri Barlian, Department of doctoral program of environmental science, Universitas Negeri Padang, Padang, Indonesia. Email: eribarlian@unp.ac.id

Dedi Hermon, Department of geography and doctoral program of environmental science, Universitas Negeri Padang, Padang, Indonesia. Email: dihermon006@gmail.com

Indang Dewata, Department of doctoral program of environmental science, Universitas Negeri Padang, Padang, Indonesia. Email: indangdewata@fmipa.unp.ac.id

Iswandi Umar, Department of geography and doctoral program of environmental science, Universitas Negeri Padang, Padang, Indonesia. Email: iswandi_u@yahoo.com

(c) The Authors. Published by Blue Eyes Intelligence Engineering and Sciences Publication (BEIESP). This is an open access article under the CC BY-NC-ND license (http://creativecommons.org/licenses/by-nc-nd/4.0/) problems that occur permanently, cumulatively, and progressively. This means the potential loss of harvest and the production of paddy, will increase from year to year, while the paddy lands like that have turned into other land-use and will not return to paddy lands [4]. Economic factors that cause the community to convert paddy lands, including economic urges to fulfil the necessities of life, the needs of settlements and other business places [5]. If this condition is allowed to take place continuously it will interfere to realize the development of sustainable agriculture.

Given the importance of implementing a sustainable development agenda, including the goals of sustainable development (SDGs), various efforts were made to achieve the targets of the SDGs work program. Most countries advise their communities to improve agricultural technology, improve soil fertility, reduce soil erosion, and increase land productivity [6]. The land is the centre of the food system, and its enormous use has caused significant environmental damage, largely due to an error in the management of agricultural ecosystems as well as human behaviour. Errors in this management will have an impact on agricultural land production [7]. Increasing food production without damaging biodiversity is a major challenge for people. There is still a trade-off between agriculture and environmental issues. Agricultural and land-use policies aimed at preserving production in a vast rural area, multifunctional and diversified agricultural landscape can contribute to simultaneously achieve protection of biodiversity and high food production [8]. Indonesia needs increased production of large paddy in the future to compensate for the rapid growth of population populations. Increased agricultural production can be done by providing inputs on the farm site. Includes mapping land resources and evaluating land suitability in each unit of land mapping. With the GIS application, input data can be quickly applied to the form of agricultural land-use map [9]. Utilizing GIS applications, this tool can map and search for potentially suitable land for paddy crops and predict paddy production in each unit of land [10]. Pagar Alam city is located in South Sumatera Province with a total area of approximately 58.304 .63 hectares, with a population of 137,909 people. The city has 5 sub-districts i.e North Pagar Alam, South Pagar Alam, North Dempo, central Dempo and South Dempo. This area is potentially a development area of various plantation crops, medicinal plants, horticulture, and food including paddy. The surface of the area is bumpy to hilly with and Inceptisol. This type of soil is very fertile and potentially for crops.

Published By:

Blue Eyes Intelligence Engineering

\& Sciences Publication

OI: 10.35940/ijmh.I0846.054920

Journal Website: www.ijmh.org

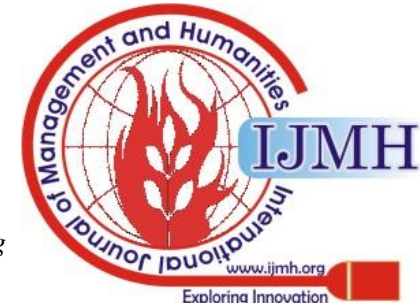


Naturally, this area is a producer of vegetables, fruits and is a Sub Terminal Agribusiness (STA) in South Sumatera province. Most of the region lies at a slope of more than $40 \%$ with a variable height of land ranging from 100-1000 m [11].

Crops require the availability of potential land because the availability of land is the most important factor in realizing the role of the sustainable agriculture sector. So that it can realize the resilience and sovereignty of food nationwide [12]. Meanwhile, in the area of Pagar Alam City, it has not been known how the conversion of paddy lands occurred lately and how the availability of potential land for each region.

The need for agricultural area planning by the potential of each region for agricultural development is necessary. To construct land-use planning is required a land survey activity. A land survey aims to produce maps that can be interrogable for various purposes. One form of interpretation of survey results is the classification of land capacity [13]. Land ability is expected to maintain balance and environmental sustainability and prevent land degradation. Improved management and conservation efforts need to be applied as the population grows, the need for land-use also increases [14]. Population growth will encourage people to open new agricultural lands, causing a decrease in the carrying capacity of agricultural land [15]. To be able to know how to support food farming land then the author plans to write research with the title of the support of land degradation based food agriculture in Pagar Alam City.

\section{METHODOLOGY}

This research used the approach of quantitative descriptive approach, with the variable concerning land-use changes, the capacity of food crops agricultural and agricultural land degradation. The samples in this study are all areas located in Pagar Alam City, which are 5 administrative areas i.e the North Pagar Alam, South Pagar Alam, North Dempo, Central Dempo, and South Dempo. The sample is a region that is planted only by paddy. As for the processing of the data is as follows:

\section{A. Land-use Changes}

Using the supervised Landsat-5 TM and Landsat-8 OIL, 2007 and 2019, processed by GIS.

\section{B. Carrying Capacity Lands for Food Crops}

Using the following calculations:

$$
\tau=(L p / P d) /(K F M / P r)
$$

Description:

$$
\begin{array}{ll}
\mathrm{T} & =\text { Capacity to support paddy food farming area } \\
\mathrm{Lp} & =\text { Paddy lands Area }(\mathrm{Ha}) \\
\mathrm{Pd} & =\text { Population (Soul) } \\
\mathrm{KFM} & =\text { Minimum physical needs } \\
\mathrm{Pr} & =\text { Average land production hectare }(\mathrm{Kg} / \mathrm{Ha})[16] .
\end{array}
$$

Based on the values then the specified classification is: Level I $\boldsymbol{\sigma}>\mathbf{2 , 4 6}$ : A region is capable of food self-sufficiency and able to provide a decent life for the population.

Level II $\mathbf{1} \leq \boldsymbol{\sigma} \leq \mathbf{2 , 4 6}$ : The territory that is capable of food self-sufficiency but has not been able to provide a decent life for its inhabitants.
Level III $\boldsymbol{\sigma}<$ 1: Areas that have not been able to food self-sufficiency.

\section{Degradation Levels of Paddy Land}

To determine the level of land degradation in the paddy land is done by determining the land capacity class where I-IV class is suitable for farming while V-VIII is not suitable for farming. To determine land support capacity based on the ability class can be done using the following formula:

$$
I K L_{w}=\frac{L W k_{1-4}}{0.3 \times L W}
$$

Description :

$\mathrm{IKL}_{\mathrm{w}} \quad=$ Regional Land Ability Index

$L W k_{1-4}=$ Area of land capability I-IV

$\mathrm{LW} \quad=$ Area

$0.3=\mathrm{A}$ minimum coefficient of $30 \%$ protection function of a region (for developing areas), while for undeveloped territories can use index 0.4 or greater.

The area's Land ability index value range is;

1. When $\mathrm{IKL}_{\mathrm{w}}>1$ means that the region can develop the potential only more optimal for various cultivation areas, with a steady balance of the environment.

2. When an $\mathrm{IKL}_{\mathrm{w}}<1$ means more territory has a protected function, its resistance to water and interference from flood problems, erosion, sedimentation, and water shortage.

\section{RESULT}

\section{A. Land-use Changes}

The result of the classification of land usage in 2007 Pagar Alam City can be seen on Fig.1and Table-I below:

Table-I: The Land-use of Pagar Alam City in 2007

\begin{tabular}{|c|l|c|}
\hline No & \multicolumn{1}{|c|}{ Land-use } & Area (Ha) \\
\hline 1 & Shrub & 938,92 \\
2 & Primary dryland forest & 9460,42 \\
3 & Secondary dryland forest & 5214,42 \\
4 & Settlements & 111,51 \\
5 & Dry-Land farming & 265,13 \\
6 & Mixed dry-land farming & 40339,45 \\
7 & Paddy lands & 2059,55 \\
8 & Open ground & 35,06 \\
\hline \multicolumn{2}{|c|}{ Total } & 58.304 .63 \\
\hline
\end{tabular}

From the Table-II of classification of land-use, it is seen that the largest use of land is dry-land agriculture mixed with an area of 40,339.45 ha. The use of rice paddy land only 2059.55 Ha. Furthermore, the land-use of Pagar Alam City 2019 can be seen on Fig.1 and Table-II below:

Table-II: The Land-use of Pagar Alam City in 2019

\begin{tabular}{|c|l|c|}
\hline No & \multicolumn{1}{|c|}{ Land-use } & Area (Ha) \\
\hline 1 & Shrub & 2681,45 \\
2 & Primary Dryland Forest & 11592,28 \\
3 & Secondary Dryland forest & 13512,50 \\
4 & Plantation & 4762,23 \\
5 & Settlements & 1680,54 \\
6 & Paddy lands & 24195,47 \\
\hline \multicolumn{2}{|c|}{ Total } & 58.304 .63 \\
\hline
\end{tabular}

Published By:

Blue Eyes Intelligence Engineering

\& Sciences Publication 
Table-II (land-use 2019) shows the large expansion of paddy lands. The community may have realized the potential of Pagar Alam City in the farming sector. It is necessary to expand the area for agricultural land-use and the need to diversify crops for higher production. The type and distribution of land-use turned out to have a significant influence on water needs [17]. For this, it takes the coordination of water resource management planning. In addition to assisting the formation of soil, water also serves as a nutrient for the roots of plants. Two interconnected functions in the provision of water for plants is to acquire water in the soil and the water flows stored in the roots of plants. Sufficient water condition, of course, is very helpful for the growth of rice crops because this plant desperately needs water in its growth process [18]. The land-use changes became a Settlements land in Pagar Alam City during the period 1995-2015, indicating an increase due to the rapid growth of the population [19]. Population increase also affected the increase of land-use for settlements in Pagar Alam City from $11.53 \mathrm{Ha}$ in 2007 to 1680.54 in 2019.
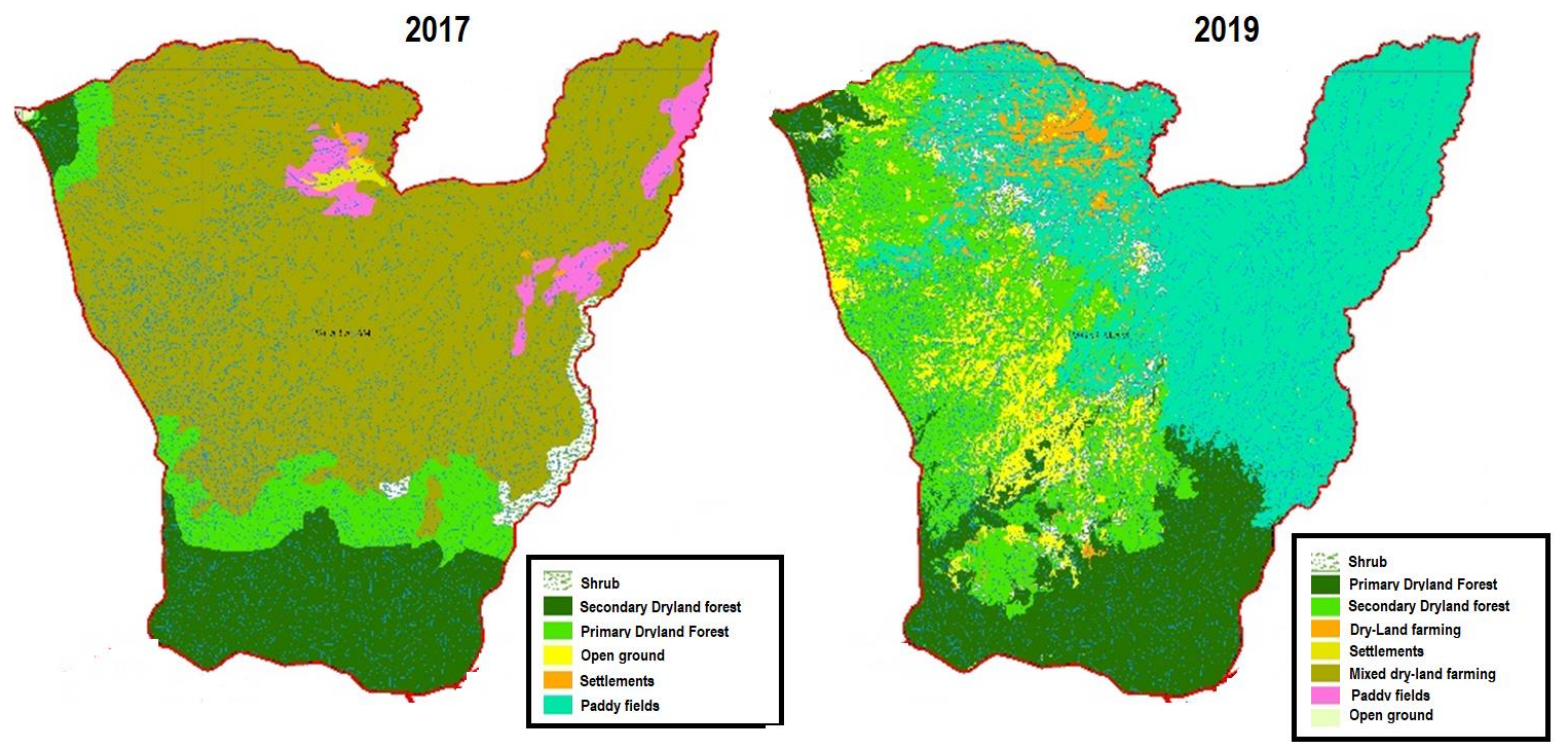

Fig.1. Map of Land-use Changes in Pagar Alam City in 2017-2019

\section{B. Carrying Capacity Lands for Food Crops}

From the data results of the carrying capacity lands that have been analyzed in Pagar Alam City, the carrying value of 4.34 is obtained which means the region can carry out food self-sufficiency and can provide a decent living for the citizens. One example of research from the Bantul Yogyakarta [20], shows the carrying capacity lands of agricultural land in Dlingo sub-districts. Only 5 sub-districts have carrying capacity of agricultural land not exceeded (DDL > 1) because do not experience population pressure (TP <1), i.e the Bantul, Banguntapan, Sewon, Kasihan, and Sedayu. Population pressure is inversely proportional to carrying capacity lands. The higher the population pressure, the lower the carrying capacity lands. Population pressure becomes a serious problem in the carrying capacity of agricultural land, because with the pressure of the population their arable. So that an increase in population will reduce the carrying capacity of lands and will increase damage [15].

Comparison of the results of research [21] in Padang City, shows that the increase in deforestation that occurred as a trigger for land damage and flooding. The conditions that have been exacerbated by climate change are extreme rain trends in Padang City. Drought at moderate to severe levels will have a significant impact especially on the agriculture sector, clean water supply, and land degradation in Padang City watershed areas [22]. While the availability of land for eating will encourage the farming community to increase

settlements in Padang City available is only 4,489 ha (6\%) of the total area [23]. For more clearly the results of data analysis of carrying capacity lands in Pagar Alam City can be seen in Table-III below.

Table-III: Data and Analysis of Carrying Capacity Lands in Pagar Alam City

\begin{tabular}{clc}
\hline No & \multicolumn{1}{c}{ Data and Analysis } & Total \\
\hline 1 & Paddy Area (square kilometres) & 24.195 \\
2 & Population & 137.909 \\
3 & Minimum physical requirement $(\mathrm{kcal})$ & 2.100 \\
4 & Average land production hectare $(\mathrm{Kg} / \mathrm{Ha})$ & 50.730 \\
5 & Harvest Area & 3.565 \\
6 & Production & 18.087 \\
7 & carrying capacity to support rice food farming area & 4,24 \\
\hline
\end{tabular}

\section{Degradation Levels of Paddy Land}

To perform this analysis, a land capability map is required. The ability map is acquired from the slope map overlay and soil characteristics map, with the parameters that are in Table-IV. The method used in land capability analysis is a matching method with the factors [12], taking into consideration the highest barriers of land capacity class. As for the land, the capacity map can be seen in Fig. 2. Visually, the map shows that most of Pagar Alam City areas have land suitability in the range of class II-IV. For more details, can be seen in Table- $\mathrm{V}$.

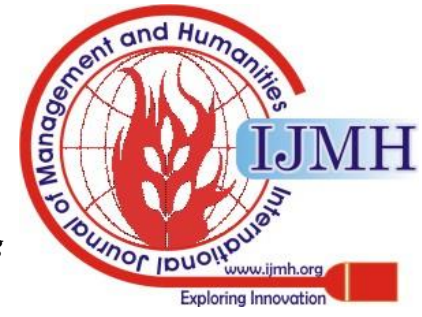


Evaluation of Carrying Capacity Lands for Food Agriculture Based on Land Degradation in Pagar Alam City - Indonesia

Table-IV: Land Capability Parameters

\begin{tabular}{|c|c|c|c|c|c|c|c|c|}
\hline \multirow{2}{*}{ Limiting factors } & \multicolumn{8}{|c|}{ Land Proficiency Class } \\
\hline & I & II & III & IV & $\mathrm{V}$ & VI & VII & VIII \\
\hline Top layer Soil texture $(40 \mathrm{~cm})$ & $\mathrm{t} 2 / \mathrm{t} 3$ & $11 / \mathrm{t} 4$ & $11 / \mathrm{t} 4$ & $\mathrm{~T} 1 / \mathrm{t} 4$ & $11 / \mathrm{t} 4$ & $11 / \mathrm{t} 4$ & $11 / \mathrm{t} 4$ & $\mathrm{t} 5$ \\
\hline Bottom layer Soil texture & $\mathrm{t} 2 / \mathrm{t} 3$ & $\mathrm{t} 1 / \mathrm{t} 4$ & $11 / \mathrm{t} 4$ & $\mathrm{~T} 1 / \mathrm{t} 4$ & $11 / \mathrm{t} 4$ & $11 / \mathrm{t} 4$ & $11 / \mathrm{t} 4$ & t5 \\
\hline Drainage & $\mathrm{d} 0 / \mathrm{d} 1$ & $\mathrm{~d} 2$ & d3 & D4 & d5 & $\mathrm{d} 4$ & $\mathrm{~d} 4$ & $\mathrm{~d} 4$ \\
\hline Solum Depth & k0 & k0 & $\mathrm{k} 1$ & K2 & k2 & k3 & k3 & k3 \\
\hline Erosion Conditions & $\mathrm{e} 0$ & e1 & e1 & E2 & e2 & e3 & e4 & e4 \\
\hline Rock out & b0 & b0 & b0 & B1 & b2 & b2 & b2 & b3 \\
\hline Flood Hazard & 0 & 1 & 2 & 3 & 3 & 3 & 3 & 3 \\
\hline
\end{tabular}

Table-V: Area of land Capability Classifications

\begin{tabular}{|c|r|r|}
\hline \multicolumn{2}{|c|}{ Land Proficiency Class } & \multicolumn{1}{|c|}{ Area (ha) } \\
\hline I & A & 0 \\
II & B & 4,93 \\
III & C & 21614,79 \\
IV & D & 21871,56 \\
V & E & 9337,49 \\
VI & F & 5235,16 \\
VII & G & 286,00 \\
\hline Total & & 58.304 .63 \\
\hline
\end{tabular}

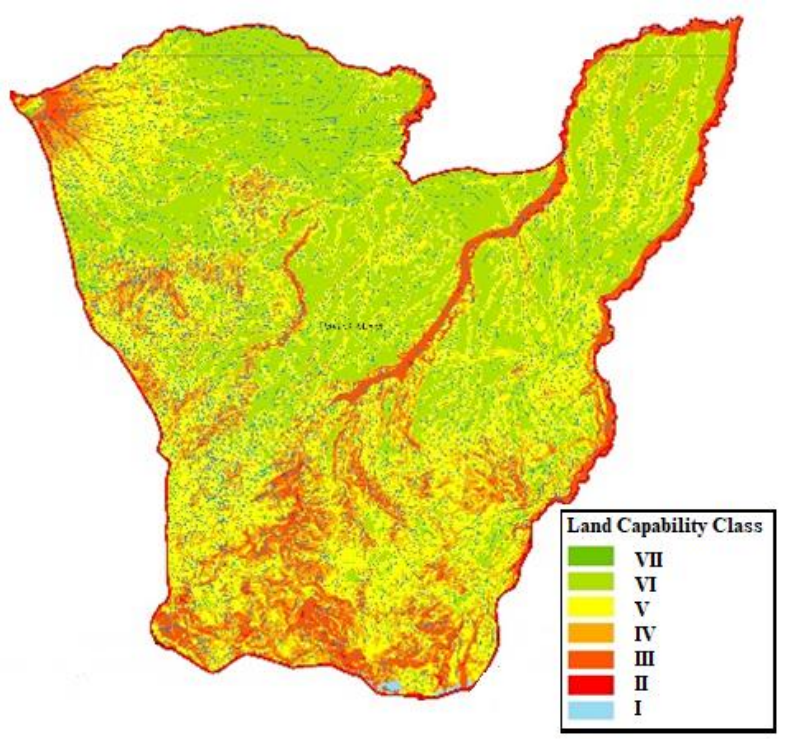

Fig. 2. Map of Land Capability of Pagar Alam City

From Tabel-V above seen as much as 75\% area of total area 58.304.63 Ha of existing land in Pagar Alam City including to the ability of land of class I-IV of 43.491.28 Ha. Considerable increase in agricultural land is caused because Pagar Alam city is a suitable area for agricultural areas, especially rice fields and plantations as well as the main commodity of agriculture, especially in the North Dempo area. While the limiting factor for this land is the slope, erosion rate and soil texture.

Pagar Alam City is still potentially developed for agricultural activities. But there are also in the class V-VII and the limiting factor that is here is the condition of steep slopes. It turns out that physiographic components play an important role in farming activities in the hills. The characteristics of the land-used are slope, depth of land, erosion, humidity, water container capacity, texture and the availability of nutrients that all of them affect agricultural production. This field of land conformity analysis can help formulate strategies for improving agricultural productivity for the future [24]. As for the data of input into the equation, and the result is as follows.

$$
I K L_{w}=\frac{43491,28}{0.3 \times 58349,92} \quad I K L_{w}=2,48
$$

The result of the equation shows the Pagar Alam City has a support index of 2.48. This figure more than 1 which means the Pagar Alam City can develop a potential only more optimal for the variety of cultivation areas, with a steady balance of the environment. For the classification of potential land of Pagar Alam City, can be known from the class in the following Table-VI below.

Table-VI: Land potential class based on land ability

\begin{tabular}{|l|l|l|}
\hline $\mathrm{IKL}_{\mathrm{w}}$ & Class & Region character \\
\hline$<0.3$ & Low & Domination of protected function \\
$0.3-0.5$ & Medium & Aquaculture activities are developing \\
$0.5-0.7$ & High & Aquaculture activities Flourish \\
$>0.7$ & Very high & Urban \\
\hline
\end{tabular}

With an index of 2.48, this means the Pagar Alam City has very high potency with the character of urban areas or can be developed into urban areas.

\section{CONCLUSION}

Pagar Alam City is located in Palembang Province with an area of approximately 58,304.63 $\mathrm{Ha}$, with a population of 137,909 people in 2017. From the results of land-use classification, it can be seen that the most extensive land use is mixed bush dryland agriculture with an area of 40,339.45 Ha in 2017 and Paddy land use is only 2059.55 Ha in 2019. From the carrying capacity value of 4.34 which means that Pagar Alam City can carry out food self-sufficiency and be able to provide a decent living for the population. While the results of the level of degradation of paddy lands are seen as much as $75 \%$ of the total area of $58,304.63$ hectares of land in Pagar Alam City, including the ability of class I - IV land area of 43,491.28 Ha. The increase in agricultural land area is quite large because the Pagar Alam City is an area suitable for agricultural areas, especially rice fields and plantations, and its main commodity is agriculture, especially in the North Dempo area. Where the results of this research can help the City Government of Pagar Alam in formulating strategies for improving agricultural productivity in the future.

\section{ACKNOWLEDGEMENT}

It Authors thank you to the Chairman of Postgraduate UNP for contributing assistance and academic direction to our research, as well as to students majoring who helped during the field survey.

Published By:

Blue Eyes Intelligence Engineering

\& Sciences Publication 


\section{REFERENCES}

1. P. Alexander, Transforming agricultural land use through marginal gains in the food system, Global Environmental Change. Vol. 57, pp. 101932, 2019

2. J. Millar and J. Roots, Changes in Australian agriculture and land use: Implications for future food security. International Journal of Agricultural Sustainability, Vol.10, Issue. 1, pp.25-39, 2012

3. A. Mulyani, K. Dwi, N. Dedi and A. Fahmudin, Analisis Konversi lahan sawah : Penggunaan Data Spasial resolusi Tinggi Mempelihatkan Laju Konversi yang Mengkhawatirkan. Jurnal Tanah dan Iklim. Vol 40, Issue. 2, pp.121-133, 2018

4. R. Nurliani, Rice-field Conversion and its Impact on Food Availability, Agriculture and Agricultural Science Procedia, Vol. 9, pp.40-46, 2016

5. Mardianto, Analisis Konversi Lahan Sawah Di Kota Solok. Jurnal Agribisnis Universitas Malikussaleh. Vol 3, Issue. 1, 2018.

6. A.A. Adenlea, W. Karin, A. Hossein, Sustainable agriculture and food security in Africa: The role of innovative technologies and international organizations Technology in Society. Vol. 58, pp.101143

7. Y. Suasti, Ahyuni, E. Barlian, B. Muchtar, N. Syah, R.Wilis, W. Prarikeslan, S. Mariya and L. Rahmi, A Typology Model of Population Growth Characteristics and Land Limitations in Regency and City, West Sumatra Province - Indonesia. International Journal of GEOMATE, 17(16), pp. 1-8, 2019

8. C. Rega, J. Helming and M.L. Paracchini, Environmentalism and localism in agricultural and land-use policies can maintain food production while supporting biodiversity. Findings from simulations of contrasting scenarios in the EU, Land Use Policy., Vol. 87, pp. 103986. 2019

9. Widiatmaka,Remote Sensing and Land Suitability Analysis to Establish Local Specific Inputs for Paddy Fields in Subang, West Java, Procedia Environmental Sciences. Vol. 33, pp. 94-107, 2016

10. K.B. Dang, Application of a hybrid neural-fuzzy inference system for mapping crop suitability areas and predicting rice yields', Environmental Modelling and Software. Vol. 114, pp. 166-180, 2019

11. Pemerintah Kabupaten Pagar Alam Satuan Tugas Penyusunan RPI2-JM. 2015. Rencana Program Investasi Infrastruktur Jangka Menengah 2015-2019

12. S. Arsyad and R. Ernan, 2012. Penyelamatan Tanah, Air, dan Lingkungan. Crestpent Press dan Yayasan Pustaka Obor Ibdonesia, 2012

13. M. Utomo, Sudarsono, R. Bujang, S. Tengku and L. Jamalam, Ilmu Tanah Dasar-Dasar dan Pengelolaan. Prenadamedia Group. Jakarta, 2016

14. D.A. Pramono, H. Teguh and B.C. Agung, Aplikasi Data Penginderaan Jauh Dan Sig Untuk Analisis Kesesuaian Penggunaan Lahan Berdasarkan Kemampuan Lahan. Prosiding Seminar Nasional Manajemen Teknologi XVIII Program Studi MMT-ITS, 2013

15. L. Muta`Ali, Daya Dukung Lingkungan untuk Perencanaan Pengembangan Wilayah. Badan Penerbit Fakultas Geografi (BPFG). Yokyakarta, 2012

16. L. Muta'ali, S.S.K. Kinasih and Sumini, Daya dukung lingkungan untuk perencanaan Pengembangan wilayah. Badan Penerbit Fakultas Geografi (BPFG), Universitas Gadjah Mada, 2012

17. I. Umar, I. Dewata and E. Barlian, Konsistensi Rencana Tata Ruang Permukiman dan Arahan Kebijakan Pembangunan di Kabupaten Tanah Datar, Provinsi Sumatera Barat. Journal of Natural Resources and Environmental Management, Vol. 9, Issue. 2, pp. 277-286. 2019

18. R. Wilis, 2017. Geografi Pertanian. Sukabina Press, 2017

19. D. Hermon, P. Iskarni, O. Oktorie and R. Wilis, The Model of Land Cover Change into Settlement Area and Tin Mining and its Affecting Factors in Belitung Island, Indonesia. Journal of Environment and Earth Sciende, Vol. 7, Issue. 6. pp. 32-39, 2017

20. S.A. Pridasari, Daya Dukung Lahan Pertanian Dan Penentuan Lahan Pertanian Pangan Berkelanjutan Di Kabupaten Bantul. Jurnal Bumi Indonesia. Vol. 7, Issue. 1, 2015.

21. I. Dewata and I. Umar. Dynamic model of forest area on flood zone of Padang City, West Sumatra Province-Indonesia. IOP Conf. Series: Earth and Environmental Science. Vol.149, pp. 012010, 2018

22. S. Nugroho and R. Wilis, The Decreasing Trend of Precipitation Observed at Watersheds in Indonesia. IOP Conf. Series: Earth and Environmental Science, Vol. 145, pp. 012099, 2018

23. I. Umar, B.P. Widiatmaka dan B. Baba, Prioritas Pengembangan Kawasan Permukiman Pada Wilayah Rawan Banjir Di Kota Padang, Provinsi Sumatera Barat. Majalah Ilmiah Globë Vol. 19, Issue.1, pp.8394, 2017

24. D. Hermon, Evaluation of physical development of the coastal tourism regions on tsunami potentially zones in Pariaman City-Indonesia. International Journal of GEOMATE, Vol. 17, Issue. 59, pp. 189-196, 2019

\section{AUTHORS PROFILE}

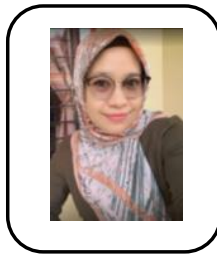

Ratna Wilis is a Research and Lecturer of Geography and Environmental Sciences, Universitas Negeri Padang, obtained the Master Degree in Soil Science at Andalas University. He is actively involved in any researches regarded to agricultural geography, soil science and produces several scientific works in the form of Scopus indexed journals (ID: 57209393371). Right now he is a student Doctoral Program of Environmental Science, Universitas Negeri Padang.

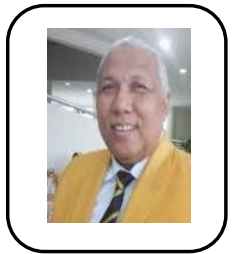

Eri Barlian is a Professor of Environmental Education, obtained the Doctorate Degree in Doctor Program Education Science at Universitas Negeri Jakarta, 1999. He is actively involved in any researches regarded to environmental education, sports, recreation and disaster and produces several scientific works in the form of Scopus indexed journals (ID: 57202293479). He is Chair of Doctoral Program of Environmental Science, Universitas Negeri Padang.

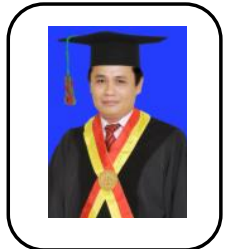

Dedi Hermon is a Professor of Disaster Geography, obtained the Doctorate Degree in Doctor Program Natural Resources Management and Environment at Bogor Agriculture University, 2009. He is actively involved in any researches regarded to natural disaster, land cover, carbon stock and produces several scientific works in the form of Scopus indexed journals (ID: 57200409691) and scientific books both national and international publications. He was the chair of the Study Program of Geography, Universitas Negeri Padang as well as a student Doctoral Program of Environmental Science, Universitas Negeri Padang.

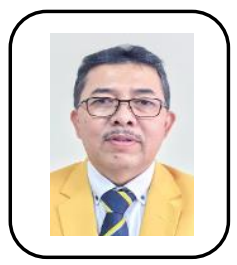

Indang Dewata is an Associate professor of Environmental Science, obtained the Doctorate Degree in Doctor Program Education Science at Universitas Indonesia, 2009. He is actively involved in any researches regarded to environmental science, chemical and produces several scientific works in the form of Scopus indexed journals (ID: 57202287960). He is Chair of Masters Program of Environmental Science, Universitas Negeri Padang.

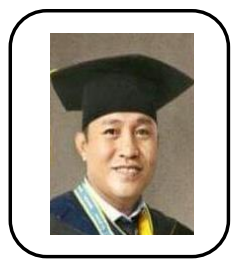

Iswandi Umar is an Associate professor of Environmental Science, obtained the Doctorate Degree in Doctor Program Natural Resources Management and Environment at Bogor Agriculture University, 2015. He is actively involved in any researches regarded to environmental science, geography and produces several scientific works in the form of Scopus indexed journals (ID: 57204825796). He is Chair of Masters Program of Geography Education, Universitas Negeri Padang.
Published By:

Blue Eyes Intelligence Engineering

\& Sciences Publication

19 (C) Copyright: All rights reserved.

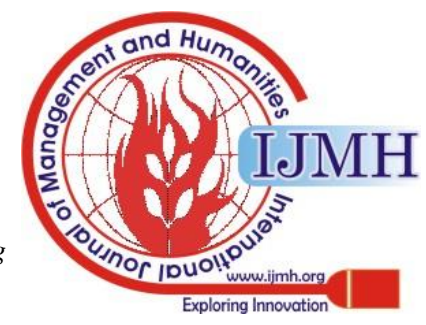

